\title{
MENGUKUR DAYA PAKSA HUKUM DALAM ISLAM
}

\author{
Holirur Rahman \\ (D osen STIT Syaichona Cholil Bangkalan, Komplek PP Syaichona Cholil JI. \\ K.H Cholil I/6 Bangkalan)
}

\begin{abstract}
A bstract:
The main characteristic of a law is capacity to force included Islamic law. Islamic law has God (rabbaniyah) as its source to people (insâniyah), that all aspects related with people concerned by Islamic law. When Islamic law is in confrontration with nation context, so a khilafah or a power that sides with the benefit and avoids kemafsadatan. It is the first and main purpose of force capacity in Islamic law. Dialectical thinking about Islam in substantif and formality becomes the irrefutable reality. The first way to make Islamic law becomes rahmatan li al-'âlamînin is actualization from Islamic law that becomes a togetherness increases people life to be better in all domain both internal and external domain.
\end{abstract}

\section{Key Words:}

Hukum Islam, insâniyah, Ilâhiyah, daya paksa, tawhid, dan Tauhid Sosial

\section{Pendahuluan}

Di antara ciri khas hukum Islam ialah bersifat insâniyah. ${ }^{1}$ Dari karakter ini memberikan pamahaman bahwa hukum Islam pada dasarnya berangkat dari pemenuhan dan perhatian kapada kebutuhan manusia. Pemenuhan tersebut terkait dengan diri, ruh, akal, aqîdah, fikrah, usaha, pahala, dan siksa baik individu maupun sosial kemasyarakatan. Sehingga pada prinsipnya semua itu dapat memberikan manfaat bagi seluruh manusia.

1Hasbi Ash-Shiddieqy, Falsafah Hukum Islam (Semarang: PT. Pustaka Rizqi Putra, 2001), hlm 142. 
Holilur Rahman

Syarî'ah telah menjadikan manusia sebagai sumber perhatian segala hukum. Segala metode pembentukan hukum Islam baik alQur'ân, sunnah Rasûl, ijmâ', qiyâs dan segala cara yang lain, juga menetapkan manusia menjadi objek kajiannya. Begitu besar perhatian al-Qur'ân hingga menjadikan manusia sebagai asas dan sumber kemudian menjadikan washilah (cara) dan ghayah (tujuan) serta menjadikannya objek pembahasan. Hal itu memberikan pengertian bahwa segala hal yang terkait dengan manusia menjadi perhatian Islam. Oleh karena itu, pernyataan kesempurnaan Islam sebagai sebuah ajaran yang memberikan pedoman bagi umatnya akhirnya menghasilkan aturan-aturan yang harus diikuti, baik secara keyakinan (aqîdah), amaliyah (syar'iyah) mapaun secara kesopanan (akhlâq). Begitu besar kekuasaan agama dalam mengatur umatnya, lebih besar daripada sebuah negara yang hanya pada lingkup kawasan tertentu. Walhasil kewenangan agama melampaui batasbatas wilayah tertentu.

Di sisi lain, kesempurnaan syarî'ah Islam hanya dipahami secara substantif. Pemahaman substantif ini pada gilirannya dapat menghasilkan sekularisme. Hal ini juga dapat terkait juga dengan klasifikasi privat dan publik serta klasifikasi agama dan negara. Ketika terjadi pemahamanan seperti ini, maka hampir dipastikan tidak ada wilayah kewenangan bagi agama untuk mengatur masyarakat, baik secara individu, masyarakat maupun kenegaraan. Menindaklanjuti pemahaman tersebut kiranya perlu dikaji secara filosofis pemahaman daya paksa hukum dalam Islam. Hal ini nantinya dapat memberikan pemahaman yang komprehensif tentang keberadaan hukum Islam secara individu, masyarakat maupun negara.

Secara historis Islam memang punya saham besar dalam terbentuknya negara ini. Tetapi mau ke mana arah dan sistem kebijakan negara ini, tidak selalu ditentukan oleh pemilik saham mayoritas. Juga bukan ditentukan oleh agama mayoritas penduduknya. Dan tentu saja bukan dengan bentuk negara negara kapitalis atau bukan kapitalis. Para pejabat negara pemegang kebijakan itu memang muslim, tetapi ilmu yang bersarang di kepala mereka bukan ilmu Islam, melainkan ilmu kapitalis. Solusi-solusi dari mereka, nyaris tidak sesuai dengan syarî'ah. Jasadnya muslim tetapi 
fikrahnya buatan luar. Oleh karena itu penegakan perlu kiranya mengacu terhadap syarî'ah.

Dari hal tersebut di atas terlihat jelas walaupun akan ada hukuman bagi orang yang berbuat dosa kelak di akhirat, namun hal itu tidak dapat menjadikan penghalang bagi manusia untuk melakukan perbuatan yang dapat merusak dan membahayakan kemaslahatan individu maupun kemaslahatan umum. Hal ini karena di antara manusia memiliki kekuatan dan kekuasaan, sementara orang yang lemah serta teraniya tidak mampu mengambil hak mereka. Karena alasan itulah diciptakan hukuman. ${ }^{2}$

\section{Bentuk-Bentuk Penegakan Hukum dalam Fiqih}

Secara prinsip ulamâ' ushûl al-fiqh menetapkan bahwa syarat pembebanan hukum ialah kemampuan mukallaf dalam melaksanakannnya. Karenanya, sesungguhnya yang tidak sanggup dikerjakan oleh mukallaf, tidak boleh dibebani baik menurut syara' maupun akal. Dalam konsep global, nash al-Qur'ân juga mengharuskan kita mengerjakan segala sesuatu, sehingga kita tetap termasuk dalam kategori muslim. Dalam Surat al-Baqarah ayat 132, Allâh swt berfirman:

$$
\text { ان الله اصطفى لكم الدين فلاتموتن الا وانتم مسلمون }
$$

"Sesungguhnya Allâh Telah memilih agama Ini bagimu, M aka janganlah kamu mati kecuali dalam memeluk agama Islam" .3

Ketika perintah yang taklîfi maupun yang wadh'î sudah ada, maka hal itu bagian dari usaha di dalam pelaksanakan hukum Islam. oleh karena itu, bentuk-bentuk penegakan hukum dalam fiqih yang terkait dengan hukum taklîfi terbagi atas: (1) Iftirâdh, yaitu tuntutan Allâh swt pada mukallaf yang bersifat memaksa dengan berdasarkan dalil yang qath'î. Misalnya tuntutan untuk melaksanakan shalat dan membayar zakat. Ayat dan Hadîts yang mengandung tuntutan mendirikan shalat dan membayar zakat sifatnya qath'î (2) Ijab atau wajib, yaitu tuntutan Allâh yang bersifat memaksa kepada mukallaf

2Ali Ahmad al-Jurjawi, H ikmat al-Tasyrî’ wa Falsafatuhu (Baerut: Dâr al-Fikr, 1994), hIm 372.

3Depag. RI., A I-Q ur' an dan T ejemahnya (Bandung: Diponegoro, 2008), hlm. 6. 
Holilur Rahman

untuk melaksanakn suatu perbuatan, tetapi melalui dalil yang bersifat dzannî. Misalnya, kewajiban membayar zakat fitrah dan membaca alFâtihah dalam shalat; (3) Nadb atau sunnah, yaitu tuntutan untuk melaksanakan suatu perbuatan yang tidak bersifat memaksa, melainkan anjuran, dalam arti bahwa orang yang meninggalkannnya tidak dikenai hukuman, misalnya menuliskan hutang piutang; (4) Ibâhah, yaitu pilihan untuk berbuat atau tidak berbuat secara sama,misalnya bolehnya berburu ketika sudah melaksanakan haji; (5) Karahah tanzihiyah, yaitu tuntutan kepada mukallaf untuk meninggalkan suatu pekerjaan, tetapi tuntutannya tidak bersifat memaksa, misalnya larangan berpuasa pada hari jum'at; (6) Karahah tahrimiyah, yaitu tuntutan kepada mukal laf untuk meninggalkan suatu perbuaatn dengan cara memaksa tetapi didasarkan kepada dalil yang dzannî. Misalnya berjualan saat shalat jumat; (7) Tahrîm, yaitu tuntutan kepada mukallaf untuk meninggalkan suatu pekerjaan secara memaksa dan didasarkan pada dalil yang qath'î, misalnya membunuh jiwa. ${ }^{4}$

Pengklasifikasian bentuk-bentuk dalam fiqih tersebut pada dasarnya berusaha menangkap maksud syara'. Dalam hal ini sedikitnya ada dua maksud tersebut, yaitu:5 Pertama, maksud ashliyah, yakni memelihara dlarurat. Dlarûriyah ini dikerjakan untuk kemaslahatan umum, tidak tertentu dengan sesuatu keadaan atau sesuatu waktu. Dari pengertian tersebut akhirnya dibagi lagi ke dalam dua macam, yakni dlarûrat 'aniyah dan dlaruriyat kifa'iyah. dlarûrat 'aniyah adalah pemeliharaan agama oleh setiap mukallaf. Seseorang diperintah untuk memelihara agamanya baik i'tikad-nya maupun amalnnya. Dia diperintah memelihara akalnya supaya dia tetap selalu memahami titah agamanya. Dia diperintah memelihara keturunannya supaya ada kelanjutan di dalam memakmurkan dunia ini. Dia diperintah memlihara harta untuk memelihara berbagai dlarûriyah yang telah Ialu. Sedangkan dlaruriyat kifa'iyah adalah pemeliharaan agama yang diwajibkan atas mukallaf secara umum supaya sempurna keadaan masyarakat. Maka dlarûriyah ini merupakan penyempurnaan dari dlarûriyah 'ainiyah dan dihubungkan

4A bd al-Wahab Khallaf, IIm U shûl Fiqh (Kuwait: Dâr al-Qalam, 1977), hlm. 14; Rachmat Syafe'i, IImu U shul Fiqih (Bandung: CV. Pustaka Setia, 1999), hlm 301. 5Hasbi, Falsafah, hlm 221. 
dengan dlarûriyah kifa'iyah karena tidak mungkin adanya dlarûriyah ainiyah tanpa tegaknya dlarûriyah kifa'iyah. Seorang manusia tidak akan dapat memperbaiki diri dan mengurusi keluarganya apalagi kelompoknya melainkan dengan jalan kerjasama. Inilah gunanya diadakan pemerintahan di muka bumi.

Kedua, maksud tab'iyah, yakni maksud yang memperhatikan kepetingan mukallaf. Dari aspek maksud ini, mukallaf memperoleh kebutuhan-kebutuhan tabi'atnya, seperti menikmati makananmakanan yang baik, memakai pakaian yang indah. Jadi maksud tab'iyah merupakan pelengkap dan penyempurnaan bagi maksudmaksud ashliyah.

Secara umum kemudian hal-hal yang bersifat dlarûriyah nantinya akan berimplikasi adanya bentuk penegakan hukum wajib dan haram. sedangkan hal-hal yang bersifat hâjiyah berimplikasi terhadap adanya sunnah yang kebalikan dari itu ketika terjadi sesuatu yang sulit untuk melaksanakannnya maka akan dibebaskan dengan istilah masaqqah. Dan hal hal yang termasuk kategori tahsiniyah akan berimpilikasi adanya sunnah dan mubah.

Adapun penjagaan penegakan hukum yang dipikirkan ulamâ' fiqih agar hukum tetap berjalan pada terciptanya ketertiban masyarakat yang dicita-citakan sebagaimana dalam syarî'ah. Teori khilâfah versi $\mathrm{A} \mathrm{hl}$ al-Sunnah wa al-Jamâ'ah pada dasarnya adalah satu legislasi bagi kenyataan yang tengah terjadi. Karena itu, satu-satunya yang diberikan oleh rujukan tradisi kepada kita adalah bahwa di dalam al-Qur'ân terdapat hukum-hukum yang membutuhkan "pemegang perintah" (waliy al-A mr) dalam Islam merupakan konsep yang luas, yakni mencakup kepala keluarga, kepala suku, ahli fiqh dan penguasa muslim di Negara Islam baik sebagai wali, amir atau khalîfah. 6

6Kata awliyâ' tersebut mengandung pengertian pengganti orang mukmin dalam segala hal. Kata "pengganti" tersebut dapat dipahami lebih luas pengertinnya, baik dalam lingkungan struktur kepemimpinan yang paling tinggi sampai ke paling rendah harus beragama yang sama, bahkan kepemimpinan yang kultural sekali pun masuk dalam cakupan kepemimpinan ini. M. Azzah Darwazah, A I-T afsiir al- $\underline{H}$ adîts: Tartib al-Suwâr Hasab al-N uzûl (Kairo: Dâr al-Garb al-Islâmi, 2000), hlm. 139. 
Holilur Rahman

Satu hal yang perlu diperhatikan di sini, yaitu bahwa al-Qur'ân menggunakan bentuk jamak para pemegang perintah ('uli al-'amr) pada ayat yang dirujuk dalam masalah pemerintahan, yaitu pada Surat al-Nisâ' ayat 59:

$$
\begin{aligned}
& \text { يايهالذين امنوا اطيعو الله اطيعو الرسول واولى الامر منكم فانتنازعتم في شيءفردوه الى الله } \\
& \text { والرسل انتتم تؤمنون بالله وليوم الاخر ذلك خير واحسن تاويلا }
\end{aligned}
$$

"Hai orang-orang yang beriman, taatilah Allâh dan taatilah Rasul (nya), dan ulil amri di antara kamu. Kemudian jika kamu berlainan pendapat tentang sesuatu, M aka kembalikanlah ia kepada Allah (AI Quran) dan Rasul (sunnahnya), jika kamu benar-benar beriman kepada Allah dan hari kemudian. yang demikian itu lebih utama (bagimu) dan lebih baik akibatnya." 7

Hal ini memberikan pemahaman bahwa tidaklah merupakan keharusan menurut agama untuk membatasi "pemegang perintah" itu hanya satu orang. Namun prinsip yang tetap ada bahwa dalam Islam terdapat hukum-hukum syara' yang pelaksanaannya memerlukan adanya pemegang perintah atau pemimpin.

Wewenang menjalankan hukuman yang diserahkan kepada pemimpin untuk kemaslahatan seorang hamba terbagi ke dalam tiga hal, yaitu: (1) hudûd, di mana ulamâ' ㅂananafiyah membaginya kelam lima macam, yaitu zina, menuduh, mencuri, merongrong, dan bajing Ioncat;; (2) ta'zîr, bisa berkaitan dengan hak Allâh (mathbut) dan hak adami; ${ }^{9}$ (3) jinâyah dan hukumannya (qishâsh dan potong tangan). ${ }^{10}$

Dari bentuk penegakan hukum tersebut pada dasarnya mampu memberikan efek jera yang efektif jika dilaksanakan sebagaimana mestinya. Namun ketika fungsi hukuman diartikan sebagai bentuk efek jera, hal ini tentunya melahirkan bentuk-bentuk penegakan

bandingkan dengan Muhammad 'A bid al-Jabiri, A I-D în wa al-D awlah wa Tathbîq alSyarî' ah (Beirut: Markaz Dirâsât al-Wahdah al-A rabiyyah, 1996), hlm 69.

7Depag. RI., A I-Q ur'an, hIm. 87.

8Lihat Wahbah al-Zuhayli, al-Fiqh al-Islâmi wa A dillatuhu (Beirut: Dâr al-Fikr, 1989), hIm 12

9lbid., hlm 195.

10lbid., hlm, 217. 
hukuman yang lain, berlanjut terciptanya ketertiban masyarakat hingga kemaslahatan di dunia dan akhirat. Namun yang patut kita sadari bahwa adanya informasi wahyu pada dasarnya memberikan petunjuk atas bentuk penegakan yang tepat. $\mathrm{Hal}$ ini karena hakikat manusia yang sesungguhnya yang paling tahu adalah si pencipta atas ciptaannya, maka bentuk hukuman yang paling efektif jika terkait dengan hak Allâh adalah bersifat qath'â, namun jika berhadapan dengan hak adami maka hal itu bersifat dzannî.

\section{Legislasi Hukum Islam sebagai Logical Extention dari Pengamalan Ajaran Islam}

Usaha untuk pembentukan hukum Islam tentunya harus mengacu terhadap sumber aslinya, yakni al-Qur'ân dan Hadîts. Ketika sumber hukum sudah berhenti, maka perlü ada pengembangan sumber terhadap permasalahan yang senantiasa berubah di setiap saat. Maka adanya qâ'idah syar'iyah baik ushûliyah maupun fiqhiyah dapat menjadi titik tolak yang lebih praktis untuk dijadikan landasan pembentukan hukum Islam.

Seiring dengan roda zaman yang terus berputar, metode pemahaman keagamaan juga melaju secara signifikan ke arah perubahan yang lebih inovatif dan kreatif. Dalam hal ini, para ulamâ' seperti dihadapkan pada sebuah kondisi riil di mana al-Qur'ân, Hadîts, ijmâ' dan qiyâs tidak lagi mampu menjawab persoalan yang mengemuka di tengah kehidupan masyarakat yang semakin problematis. Oleh karenanya, mereka terus berupaya untuk menciptakan dan menggunakan perangkat pembantu yuridis yang diharapkan mampu mengatasi setiap masalah yang timbul. Di antara mereka, ada yang menggunakan istihnsân, mashlahahah mursalah, istishhââ, 'urf dan perangkat pembantu yang lain."1 M elalui bantuan perangkatperangkat inilah, para ulamâ' berharap figh akan tetap eksis mengiringi gejolak kehidupan yang selalu berubah serta mampu memberikan solusi hukum bagi setiap permasalahan.

Salah satu bentuk upaya pengembangkan pemahaman terhadap permasalahan hukum terkait dengan perubahan sosial sehingga hukum Islam tampak dinamis dalam menyikapi permasalahan

11Khallaf, IImu, hIm 14-121. 
Holilur Rahman

kontemporer yang disebabkan perkembangan zaman. Hakikat dinamisasi ditunjukkan dengan merumuskan kembali ketentuan hukum dengan mengedepankan relasi teks dengan konteks. Terlebih tujuan utama disyariatkan hukum adalah untuk kemaslahatan umat manusia. Kemaslahatan tersebut bersifat dinamis dan fleksibel. Maksudnya, pertimbangan kemaslahatan tersebut seiring dengan perkembangan zaman. Sebagai konsekuensinya, bisa jadi yang dianggap maslahat pada masa lalu belum tentu dianggap maslahat pada masa sekarang.12 Namun demikian, para ulamâ' seringkali menggunakan pendekatan historis dan sosiologis ketika membahas persoalan hukum. Dengan demikian, hukum Islam ditangan ulamâ' tampil dinamis sesuai dengan konteks zamannya. ${ }^{13}$

Kemajuan umat Islam dalam hal metodologi dan aplikasi hukum serta peradabannya, ternyata membuat bangsa Barat tidak tinggal diam. Mereka, yang dahulu berada dalam kekuasaan pemerintahan Islam, akhirnya mampu menyusun kekuatan dan berhasil mencari serta menemukan momentum yang tepat guna menghancurkan Islam beserta peradabannya. Serangan yang dilakukan oleh bangsa Barat tidak hanya bersifat militer, namun peperangan intelektual juga mereka lancarkan. Daerah-daerah Islam yang berhasil ditaklukkan, dipaksa tunduk dan patuh pada aturan mereka. Dan peristiwa inilah yang menjadi titik awal persinggungan antara Figh Islam dengan aturan-aturan (hukum) yang dibuat oleh bangsa Barat. Peristiwa ini sekaligus menandai dimulainya sejarah baru, di mana abad modern dengan segala dinamikanya bertemu sapa secara dialektis dengan hukum Islam.

Menurut al-Qatthan, bagian dari hukum Islam yang menjadi sasaran pertama ekspansi Barat adalah hukum pidana dan hudûd. Ini dapat dibuktikan dari adanya pelaksanaan hukum pidana Barat di beberapa wilayah Islam pada masa pemerintahan Utsmâniyah. Hukum pidana yang diberlakukan pada saat itu adalah produk perundang-undangan Perancis. Fenomena ini mengakibatkan status hukum Islam menjadi semakin tidak jelas dan terkatung-katung. ${ }^{14}$

12Mahmud Syaltut, A I-Islâm A qîdah wa Syarî'ah, (Beirut: Dâr al-Qalam, 1966), hlm 44. 13Mahmud Syaltut, A I-F atâw qa, (Beirut: Dâr al-Syuruq, 1972), hlm 172.

14Mannâ' al-Qaththan, al-Tasyrî' wa al-Fiqh fî al-Islâm: Tarîkhan wa M inhajan (Kairo: Maktabah Wahbah 2001), hlm 400. 
Fiqh yang seharusnya diterapkan dalam setiap persoalan, kini ia tidak bisa diterapkan dalam masalah pidana dan hudûd. Pemerintah justeru memberlakukan sistem hukum yang dibuat oleh kaum penjajah (Barat).

Peristiwa pemberlakukan hukum positif di kawasan pemerintahan Islam tidak hanya terjadi di daerah kekuasaan Daulah Utsmâniyyah saja. Di Mesir, tarik-menarik antara penerapan hukum Islam dengan penerapan hukum positif (Barat) juga terjadi. Dan hukum Islam pun akhirnya harus puas berkiprah hanya pada tingkat wacana. Sedangkan dalam aplikasinya, pemerintah lebih memilih untuk menerapkan sistem hukum positif. Bahkan, hukum positif yang diberlakukan di Mesir tidak hanya menyangkut masalah pidana, namun dalam masalah perdata juga diterapkan.

Bagaimanapun antara syariat Islam dengan sistem perundangundangan positif yang dibuat bangsa Barat jelas-jelas berbeda dari sisi manhaj dan karakteristiknya. Meskipun diakui memang terdapat beberapa persamaan antara keduanya, namun apa yang dilakukan oleh sebagian Ulamâ' mesir dengan memberikan sifat syar' iyyah pada hukum positif adalah sebuah kesalahan yang fatal.15

Adapun keberadaan figh sebagai model hukum Islam pada periode modern semakin tidak jelas. Penerapannya menjadi hal yang paradoksial. Bagaimana tidak, Umat Islam di satu sisi sangat berharap bisa memiliki tatanan hukum yang benar-benar dari ajaran agamanya. Sementara di sisi lain, mereka dihadapkan pada kenyataan bahwa ada sistem hukum baru yang lebih sistematis dan diterima serta diberlakukan oleh sebagian pemerintah Islam di beberapa kawasan. Ironisnya, sistem hukum ini berasal dari para penjajah Islam yang sudah barang tentu banyak merugikan kaum Muslim.

Pro-kontra terhadap sesuatu yang baru adalah hal yang wajar dalam kehidupan. Begitu pula dengan adanya sistem hukum positif yang mulai masuk di kawasan Islam. Memang benar bahwa di Mesir dan di beberapa kawasan Daulah Utsmâniyyah pemerintah menerima

15lbid, hlm 401. 
Holilur Rahman

dan memberlakukan sistem hukum positif dalam wilayah pemerintahannya.

Namun, bertolak belakang dengan kenyataan ini, muncul gerakan-gerakan Islam yang menentang kebijakan pemerintah tersebut. Mereka mengajak kaum Muslim untuk kembali kepada ajaran Islam yang murni (bersumber dari al-Qur'ân dan al-Sunnah). Gerakan ini juga menyerukan jihad (perang) kepada mereka yang dianggap sebagai musuh Islam, terutama bangsa Barat. Dari gerakangerakan inilah lahir tokoh seperti, Muhammad bin Abd al-Wahhab (Wahabi), Jamal al-Dîn al-Afghâni, serta al-Syahid 브asan al-Bannâ (Ikhwân al-Muslimîn).

Peristiwa dialektis antara hukum Islam (figh) dengan realitas yang mengitarinya, ternyata benar-benar membawa perubahan berarti bagi wacana, sistematisasi dan aplikasi Hukum Islam di kehidupan modern. Para ahli Hukum Islam pun terus menerus melakukan ijtihâd guna menemukan format terbaik bagi terlaksananya penerapan hukum yang Islami. Mereka ada yang melakukannya secara perorangan (ijtihâd fardlî) dengan menyusun berbagai karya tulis dengan metode penulisan yang lebih sistematis tentang hukum Islam (figh) dan ada pula yang melibatkan dirinya secara aktif pada lembaga-lembaga kajian hukum Islam (ijtihâd jamâ'î), seperti yang dibentuk oleh Universitas al-A zhar, Kairo.

Di samping kedua hal ini, menurut al-Qatthan, para ulamâ' juga telah melakukan beberapa pembenahan secara akademis dalam upaya pengembangan wawasan tentang pembaharuan hukum Islam. Dibukanya fakultas hukum di beberapa perguruan tinggi (Islam) serta sering dilakukannya seminar tentang hukum adalah bukti dari upaya tersebut. 16

Jadi yang perlu diketahui juga bahwa penerapan hasil legislasi hukum Islam agar dapat ditegakkan harus bermula dari orang yang memiliki kekuasaan atau wewenang. Adanya khilâfah merupakan salah satu bentuk legislasi dalam sejarah Islam. Bentuk kekuasaan

16lbid, hlm 405. 
Mengukur Daya Paksa Hukum

dan wewenang dalam Negara menjadi salah satu bentuk metamorfosis dari legislasi hukum Islam. ${ }^{17}$

\section{H ukum dan Cita-cita Sosial Islam}

Doktrin tawhid yang menjadi ruh kekuatan Islam tidak pernah hilang dari perjalanan sejarah, walaupun aktualisasinya dalam dimensi kehidupan tidak selalu menjadi kenyataan. Dengan kata lain, kepercayaan kepada ke-Esa-an Allâh belum tentu terkait dengan prilaku umat dalam kiprah kesejarahannya. Padahal, sejarah membuktikan bahwa tawhid menjadi senjata yang hebat dalam menancapkan pilar-pilar kesejarahan Islam.

Dalam konteks ini, orang kemudian mempertanyakan praktik sosial Islam yang dianggap tidak komprehensif. Praktik sosial Islam ini banyak dibahasakan dengan berbagai istilah, antara lain Tauhid Sosial. Syafi'i Ma'arif menyebutkan Tauhid Sosial sebagai dimensi praksis dari risiko keimanan kepada Allâh SWT. 18 Doktrin ini sudah sangat dini dideklarasikan al-Qur'ân, yaitu pada masa Makkah tahuntahun awal. Secara substasial, gagasan Tauhid Sosial Syafi'i Ma'arif menggambarkan dua hal:19 Pertama, iman adalah kekuatan yang menjadi pilar utama perjalanan sejarah umat Islam. Memilih Islam adalah menjalani suatu pola kehidupan yang utuh dan terpadu (integrated), di bawah prinsip-prinsip tawhid. Setiap aspek kehidupan yang dijalani merupakan refleksi dari prinsip-prinsip tauhid itu. Islam menolak pola kehidupan yang fragmentatif, dikotomik, dan juga sinkretik. Praktik kehidupan seperti ini telah ditunjukkan dalam perjalanan kerasulan Muhammad yang diteruskan oleh sebagian generasi setelahnya. Islam berprinsip pada tawhid, lebih dari segalanya. Sehingga kekuatan tawhid inilah yang menjadi pengawal dan pusat dari semua orientasi nilai.

Kedua, iman harus mampu menjawab dimensi praksis persoalan keummatan. Artinya, kekuatan tawhid ini harus diaktualisasikan, bukan hanya tersimpan dalam teks-teks suci. Masyarakat yang adil harus didirikan dalam prinsip al-'amr bi al-

17Lihat al-Jabiri, al-D în, 68. bandingkan dengan al-Jurjawi, H ikmat, hlm 376.

18Syafi'i Ma'arif, Islam Kekuatan D oktrin dan Kegamangan U mat (Yogyakarta: Pustaka Pelajar, 1997), hlm 5.

$19 \mathrm{bid}$., hlm 8. 
Holilur Rahman

ma'rûf wa al-nahy 'an al-munkar'. Dalam al-Qur'ân, doktrin al-'amr bi alma'rûf wa al-nahy 'an al-munkar' dijumpai dalam delapan ayat, tersebar dalam lima surat, dua Makkiyah dan tiga Madâniyyah. Tugas ini dibebankan pada Rasûl, pemerintah dan umat yang beriman secara keseluruhan, yang kemudian terwujud dalam dimensi sosial, politik, ekonomi dan budaya. ${ }^{20}$

Karena itulah, demikian Ma'arif, kalau kita tidak mampu mencari penyelesaian secara Islam bagi persoalan-persoalan kemasyarakatan dan kemanusiaan, maka pilihan yang menunggu di hadapan kita adalah sekularisme. Ini artinya secara tidak langsung kita membenarkan pendapat sementara orang bahwa Islam telah kehilangan relevansinya dengan nuansa zaman. Ungkapan Islam yang serba kâffah, sebenarnya mengandung kebenaran, tetapi masih terlalu jauh dari substansi permasalahannya. Ini tidak begitu mengherankan karena sumber informasi yang mereka terima umumnya berasal dari literatur yang secara ilmiah sulit dipertanggungjawabkan. Literatur itu bisa saja secara emosional sangat memikat, tapi bila dibawa turun ke bumi tidak banyak yang dapat digunakan bagi penyelesaian masalah-masalah sosial umat. Karena itu, konsep Islam yang serba kâffah itu yang dilihat terutama adalah wilayah-wilayah pinggir, yang bila perlu mau mati syahid untuk mempertahankan wilayah marjinal itu.

Dalam perspektif yang berbeda, cendekiawan Muslim, Kuntowojoyo, menyatakan bahwa nilai-nilai Islam sebenarnya bersifat all-embracing bagi penataan sistem kehidupan sosial, politik, ekonomi dan budaya. Oleh karena itu, tugas terbesar Islam sebenarnya adalah melakukan transformasi sosial dan budaya dengan nilai-nilai tersebut. Di dalam al-Qur'ân kita sering sekali membaca seruan agar manusia itu beriman, dan kemudian beramal. Dalam surah al-Baqarah ayat kedua misalnya, disebutkan bahwa agar manusia itu menjadi muttaqîn, pertama yang harus ia miliki adalah iman, 'percaya kepada yang gaib', kemudian mendirikan shalat, dan menunaikan zakat. Di dalam ayat tersebut kita melihat adanya trilogi

20 Murtadha Mutahhari, Perspektif A I-Q ur'an tentang M anusia dan Agama (Bandung: Mizan, 1984), hlm 20. 
iman-shalat-zakat. Sementara dalam formulasi lain, kita juga mengenal trilogi iman-ilmu-amal. Dengan memperhatikan ini, kita dapat menyimpulkan bahwa iman berujung pada amal, pada aksi. Artinya, tawhid harus diaktualisasikan: pusat keimanan Islam adalah Tuhan, tetapi ujung aktualisasinya adalah manusia.21

Dengan demikian, Islam menjadikan tawhid sebagai pusat dari semua orientasi nilai. Sementara pada saat yang sama melihat manusia sebagai tujuan dari transformasi nilai. Dalam konteks inilah Islam disebut sebagai rahmatan li al-'alamin, rahmat untuk alam semesta, termasuk untuk kemanusiaan. Dengan melihat penjelasan ini, tawhid sosial sebenarnya merupakan perwujudan aksi sosial Islam dalam konteks menjadikannya sebagai rahmatan li al-'alamin. Proses menuju ke arah itu harus dimulai dari penguatan dimensi tawhid, kemudian dimensi epistemik, lalu masuk dalam dimensi amal berupa praktik sosial kepada sesama manusia.

\section{Penutup}

Sebagai akhir dari uraian ini dapat simpulkan beberapa hal, yaitu: (1) Daya paksa dalam hukum Islam pada dasarnya senantiasa mengacu terhadap kepentingan manusia karena karakter hukum Islam universal dan untuk dilaksanakan (3) Bentuk penegakan hukum Islam senantiasa bersifat probabilitas. Karena manusia berada dalam dimensi ruang dan waktu yang menuntut terjadinya suatu kepastian dalam kehidupannnya; (4) Pembentukan hukum Islam senantiasa bersifat rabbaniyah karena pada diri manusia tersirat hakikat kesucian yang mengarah pada kebaikan yang abadi. Namun pada aspek aplikasi metode yang digunakan bisa saja berubah-ubah karena bersifat realtif; (5) Penerapan hasil legislasi hukum Islam agar dapat ditegakkan harus bermula dari orang yang memiliki kekuasaan atau wewenang. A danya khilafah, kerajaan dan Negara merupakan salah satu bentuk legislasi dalam Islam; (6) Hukum dan cita-cita sosial mengharap terbentuknya masyarakat yang berdimensi tauhidiyah, sehingga pada pengembangannya manusia akan menjadi shalih individual dan shalih sosial.

${ }^{21}$ Kuntowijoyo, Paradigma Islam: Interpretasi untuk aksi (Bandung: Mizan, 1991), hlm 28. 
Holilur Rahman

\section{D aftar Pustaka}

Darwazah, M. Azzah. Al-Tafsîr al-ㅂaîts: Tartib al-Suwâr $\underline{H}$ asab alN uzul. Kairo: Dâr al-Garb al-Islâmi, 2000.

Jabiri, Abid al-. Al-Dîn wa al-D awlah wa Tathbîq al-Syarî'ah. Beirut: Markaz Dirâsât al-Wahdah al-A rabiyyah, 1996.

Jurjawi, Ali A hmad al-. Hikmat al-Tasyrî’ wa Fal safatuhu. Beirut: Dâr alFikr, 1994.

Khallaf, A bd al-Wahab. IIm U shûl Fiqh. Kuwait: Dar al- Qalam, 1977.

Kuntowijoyo. Paradigma Islam: Interpretasi untuk aksi. Bandung: Mizan, 1991.

Ma'arif, Syafi'i. Islam Kekuatan Doktrin dan Kegamangan U mat. Yogyakarta: Pustaka Pelajar, 1997.

Mutahhari, Murtadha. Perspektif A I-Q ur'an tentang M anusia dan Agama. Bandung: Mizan, 1984.

Qatthan,Manna' al-. Tasyrî' wa alFigh fî al-Islâm: Tarikhan wa M inhajan. Kairo: Maktabah Wahbah 2001.

Ash-Shiddieqy, Hasbi. Falsafah Hukum Islam. Semarang: PT. Pustaka Rizqi Putra, 2001.

Syafe'i, Rachmat. IImu U shul Fiqih. Bandung: CV. Pustaka Setia, 1999.

Syaltut, Mahmud. Al-Islâm 'A qîdah wa Syarî'ah. Kuwait: Dâr al-Qalam, 1966.

, A I-Fatâwâ.Beirut: Dâr al-Syuruq, 1972.

al-Zuhayli, Wahbah. al-Fiqh al-Islâmîi wa Adillatuhu. Beirut: Dâr alFikr, 1989. 